\title{
Total Phenolics, Antioxidative and Antimicrobial Activities of Some Edible Ascomycota Collected from Niğde
}

\author{
Şükrü Canpolat ${ }^{1, a, *}$, Ilgaz Akata ${ }^{2, b}$, Yasemin İşlek $^{3, c}$, Elif Canpolat $^{4, \mathrm{~d}}$, Cemil İşlek $^{4, e}$ \\ ${ }^{1}$ Central Laboratory Research Center, Niğde Ömer Halisdemir University, 51240 Niğde, Turkey \\ ${ }^{2}$ Department of Biology, Faculty of Science, Ankara University, 06560Ankara, Turkey \\ ${ }^{3}$ Department of Electronics and Automation, Vocational School of Technical Sciences, Niğde Ömer Halisdemir University, 51240 Niğde, Turkey \\ ${ }^{4}$ Deparment of Biotechnology, Faculty of Arts and Science, Niğde Ömer Halisdemir University, 51240 Niğde, Turkey \\ *Corresponding author
}

\section{A R T I C L E IN F O A B S T R A C T}

\section{Research Article}

Received : 17/08/2021

Accepted : 27/09/2021
Mushrooms have been used as food and medicinal purposes for centuries. In this study, some edible Ascomycota were collected in 2018 and 2019 from Niğde, Turkey. Molecular identifications of the samples were performed afterward. PCR products were sent for sequence analysis after ITS fragments were amplified with suitable primers concerning DNA isolation of samples. The obtained data were compared with the Genbank database for samples' determination. The mushroom samples were determined to be Terfezia claveryi Chatin and Morchella esculenta (L.) Pers. Samples were extracted by ethanol and methanol to determine antimicrobial activity using the disc diffusion method. Antimicrobial zones against microorganisms were measured. Then DPPH radical scavenging effects and total phenolic content of $T$. claveryi and $M$. esculenta mushroom samples were studied. The highest antimicrobial activity was observed in ethanol extracts of M. esculenta. When the DPPH radical scavenging activities are taken into account, the activity is increased depending on the concentration. The highest DPPH scavenging activity was found in the extract of M. esculenta with $40.86 \%$. It was determined that the total phenolic substances in methanol extracts of mushroom samples varies between $533.28 \pm 1,15-537.34 \pm 2.20 \mu \mathrm{g}$ GAE / mg extract.
Keywords:

T. claveryi

M. esculenta

Antimicrobial activity

Antioxidant

Nigde sukrucanpolat@ohu.edu.tr ymeric@ohu.edu.tr e cislek@ohu.edu.tr

\section{iD https://orcid.org/0000-0001-8223-7260 (iD) https://orcid.org/0000-0002-1823-6746 (iD) https://orcid.org/0000-0002-6690-2846}

b@akata@science.ankara.edu.tr elif.yurumez@ohu.edu.tr https://orcid.org/0000-0002-1731-1302

(iD https://orcid.org/0000-0003-1470-1169

\section{(c) (i) (3) This work is licensed under Creative Commons Attribution 4.0 International License}

\section{Introduction}

The traditional identification of the edible Ascomycota is based on the characteristics of morphological structures such as shape, size and color of the ascocarp, gleba, and ascospores. Since these characteristics are highly dependent on the environmental conditions identification by morphological structures may be misleading at the 'species' level. Thus, DNA-based methods are widely used for avoiding such problems. The Internal Transcribed Spacer (ITS), which is an approximately 700bp long and highly conserved region of the nuclear DNA is generally used as a molecular marker for the identification of the fungal species due to its high inter-species variation (Giusti et al., 2021).

Edible Ascomycota have long been consumed by humans both for food and medicinal purposes since they have high digestible protein, essential fatty acids content (Doğan and Aydın, 2013) and bioactive compounds that have antioxidant, anti-inflammatory, antitumoral, antimicrobial, antidiabetic, antiallergic and immune system boosting effects (Janakat et al., 2004; Badalyan, 2012; Akyüz et al., 2019; Sevindik, 2020), as well as their unique taste and flavor.

Oxidative stress due to the accumulation of the reactive oxygen species (ROS) produced in living organisms, as a result of energy-producing reactions, may lead to serious diseases such as Parkinson's, Alzheimer's, cancer and cardiovascular disorders (Sevindik et al., 2018). In some cases, supplemental antioxidants are needed when endogenous antioxidants produced by the organisms to suppress ROS are inadequate (Bal et al., 2019). Extracts of Ascomycota fungi are known to have high antioxidant activity (Sevindik and Akata, 2019; Sarıdoğan et al., 2021) due to the high phenolic compounds and other secondary metabolite content of the fungal species (Taşkın et al., 
2021). Moreover, fungal extracts show various levels of inhibition against pathogen microorganisms (Gücin and Dülger, 1997; Duman et al., 2003; Akpi et al., 2017; İşlek et al., 2021). Since antibiotic resistance developed by pathogen microorganisms is a global concern, studies on searching novel antimicrobial agents have indicated that fungal species have a great potential in this era (Lindequist et al., 2005; Doğan et al., 2013; Sevindik et al., 2016; Badalyan et al., 2019).

In this study it was aimed to determine the content of total phenolic compounds, antioxidative and antimicrobial activity of the crude extracts of some edible Ascomycota collected in 2018 and 2019 from Niğde, Turkey.

\section{Materials and Methods}

\section{Materials}

Macrofungi samples were collected from different locations in Niğde between the years 2018 and 2019. All samples were photographed in their natural habitats. Environmental conditions and altitudes were noted. All samples were identified by Associate Professor Dr. Ilgaz AKATA, Ankara University. Identified samples were then freeze-dried and stored at the laboratory in the Biotechnology Department of Niğde Ömer Halisdemir University.

\section{DNA Extraction and Molecular Identification}

For supporting morphological identification and eliminate possible confusions at a species level, molecular identification based on Internal Transcribed Spacer (ITS) regions of the rDNA, which is widely used for discriminating fungal species, was also performed (White et al., 1990; Schoch et. al., 2012; Vu et al., 2019).

DNA extractions from samples were performed by the Macherey-Nagel ${ }^{\text {TM }}$ Nucleospin Plant II DNA extraction kit with slight modifications in the supplier instructions. ITS regions were amplified by Polymerase Chain Reaction (PCR) with ITS-1 (5'-TCCGTAGGTGAACCTGCGG-3') and ITS-4 (5'-TCCTCCGCTTATTGATATGC-3') primers which are forward and reverse, respectively. After agarose gel electrophoresis PCR products were sent to BM Labosis (Ankara, Turkey) for sequence analysis. Macrofungi samples were identified by comparing the data obtained from sequence analysis with National Center for Biotechnology Information (NCBI) GenBank database via Basic Local Alignment Search Tool (BLAST).

\section{Preparation of Fungal Extracts}

Dried macrofungi samples were weighed $(10 \mathrm{~g})$, ground into a powder with mortar and pestle, mixed with $100 \mathrm{~mL}$ solvent (ethanol and methanol separately for each sample), and incubated at $30^{\circ} \mathrm{C}$ for 48 hours at $150 \mathrm{rpm}$. After incubation extracts were filtered through Whatman No:1 filter papers and solvents were removed by a rotary evaporator. Obtained extracts were stored at $+4^{\circ} \mathrm{C}$ until use.

\section{Determination of Antioxidant Activity}

The antioxidant potential of fungal extracts was evaluated by the DPPH scavenging method. DPPH $(2,2$ diphenyl-1-picrylhydrazyl) is a dark-colored powder comprised of stable free radicals showing maximum absorbance at $517 \mathrm{~nm}$ (Shimada et al., 1992). 0,1 mM DPPH solution and a serial dilution of fungal extracts-5 grade with a volume of $500 \mu \mathrm{L}$ - were prepared with ethanol. $100 \mu \mathrm{L}$ extract was added onto $2.9 \mathrm{~mL} \mathrm{DPPH}$ solution to form a mixture with a final volume of $3 \mathrm{~mL}$. The mixture was then incubated at room temperature for 15 minutes and the absorbance was measured by a spectrophotometer at $517 \mathrm{~nm}$. DPPH scavenging activity of the extracts was evaluated by the formula below where \% $\mathrm{SA}$ is \% DPPH scavenging activity of extracts, ADPPH is the absorbance of DPPH at $517 \mathrm{~nm}$ and ASample is the absorbance of the sample at $517 \mathrm{~nm}$.

$$
\% \mathrm{SA}=\frac{\mathrm{A}_{\mathrm{DPPH}}-\mathrm{A}_{\text {Sample }}}{\mathrm{A}_{\mathrm{DPPH}}} \times 100
$$

\section{Determination of Total Phenolic Compounds}

Total phenolic compound analysis was conducted using Folin-Ciocalteu's reagent, which is also known as the Gallic acid equivalence (GAE) method. Gallic acid was used to establish the standard curve for the total phenolic content. $1 \mathrm{~mL}$ of Folin-Ciocalteu's phenol reagent was added to $100 \mu \mathrm{L}$ of each sample and shaken. After $5 \mathrm{~min}$, $1 \mathrm{~mL}$ of $(6 \%) \mathrm{Na}_{2} \mathrm{CO}_{3}$ solution was added to the mixture and incubated at room temperature for 90 minutes. The absorbance of the samples was measured at $765 \mathrm{~nm}$ by a spectrophotometer. Total phenolic compounds were expressed as $\mu \mathrm{g}$ GAE/g (Singleton et al., 1999).

\section{Antimicrobial Activity Test}

Disc diffusion method was applied to evaluate the antimicrobial activity of the fungal extracts against selected microorganisms. Escherichia coli ATCC 25922, Staphylococcus aureus ATCC 25923, Pseudomonas aeruginosa DSMZ 50071, Salmonella typhimurium SL1344, Bacillus subtilis DSMZ 1971 strains were used as test microorganisms. Microorganisms were inoculated in Luria-Bertani (LB) medium and incubated at $37^{\circ} \mathrm{C}$ for 24 hours. The turbidity of the microbial cultures was in accordance with the $0.5 \mathrm{McF}$ arland standard.

$100 \mu \mathrm{L}$ of microorganisms were plated on LB agar medium with a sterile drigalski spatula. 15,30 and $60 \mu \mathrm{L}$ of fungal extracts were applied on sterile paper discs with a diameter of $6 \mathrm{~mm}$. Discs were then placed on an agar medium and incubated at $37^{\circ} \mathrm{C}$ for 24 hours. Antibiotic discs containing gentamycin $(10 \mu \mathrm{g} / \mathrm{disc})$ and vancomycin $(30 \mu \mathrm{g} / \mathrm{disc})$ were used as positive control and solvents (ethanol or methanol) were used as a negative control. After incubation, diameters of the inhibition zones against test microorganisms were measured and expressed in mm.

\section{Results and Discussion}

\section{Identification of Samples}

The fruiting bodies that constitute the material of this study were identified both morphologically according to the current literature (Breitenbach and Kränzlin, 1984) and molecularly by comparing the data obtained from sequence analysis with the NCBI GenBank database. GenBank is the most comprehensive and widely used database for researchers and most of the identifications of fungal species deposited in the GenBank were performed using the ITS region of the nuclear DNA as a standard marker 
(Badotti et al., 2017). In this context, investigated fungal samples of this study were identified as $T$. claveryi and $M$. esculenta with a similarity rate of 100 and $99.2 \%$, respectively.

\section{Antimicrobial Activity}

In our study, the antimicrobial activities of ethanol and methanol extracts of $T$. claveryi and M. esculenta at 15, 30 and $60 \mathrm{mg} / \mathrm{mL}$ concentrations against E. coli, $P$. aeruginosa, S. aureus, B. subtilis, S. typhimurium were investigated. The results are shown in tables 1, 2 and 3.

The inhibition zones against test organisms of the antibiotic discs containing gentamycin and vancomycin were used as reference (Table 1) to determine the antimicrobial activity of the fungal extracts.

While the highest antimicrobial activity was obtained from $T$. claveryi at $60 \mathrm{mg} / \mathrm{mL}$ ethanol concentration $(27 \pm$ $0.6 \mathrm{~mm}$ ) against $E$. coli ATCC 25922 bacteria, the lowest antimicrobial activity was against $S$. typhimurium SL1344 bacteria at $15 \mathrm{mg} / \mathrm{mL}$ methanol concentration $(8.7 \pm 0.6$ $\mathrm{mm}$ ) was determined in $T$. claveryi (Table 2).

Janakat et al. (2004) investigated the in vitro antimicrobial activities of aqueous and methanolic extracts of $T$. claveryi against $S$. aureus. They showed that $5 \%$ aqueous extracts inhibited the growth of $S$. aureus by $66.4 \%$, but methanolic extracts did not have a significant effect. It has been determined that methanolic extracts of Terfezia species have antimicrobial effects especially against $B$. subtilis and $S$. aureus (Hussan and Al-Ruqaie, 1999).

In a study, they investigated the in vitro antimicrobial activities of aqueous and methanolic extracts of $T$. claveryi against $P$. aeruginosa. The aqueous extract of the mushroom inhibited the growth of $P$. aeruginosa by
$40.9 \%$, while the methanolic extract was found to be ineffective.

It has been emphasized that the antimicrobial activities of $T$. claveryi may vary depending on the test method used, the microorganism species and the chemicals used (Inci and Kırbağ, 2018).

Ethanol extracts of $M$. esculenta did not show any antimicrobial effect on B. subtilis DSMZ 1971 bacteria (Table 3). Eraslan et al., 2021 found that ethanol extract of $M$. esculenta showed the highest antimicrobial activity against $S$. aureus, E. faecalis and E. coli at a concentration of $50 \mu \mathrm{g} / \mathrm{mL}$. The mushroom extract was also effective against $P$. aeruginosa at $50 \mu \mathrm{g} / \mathrm{mL}$ concentration.

In a study in which the antimicrobial activity of $M$. esculenta ethanol extract against 11 microorganisms was analyzed, low antimicrobial activity was determined against $S$. aureus, S. lutea, S. typhimurium and C. albicans (Kalyoncu et al., 2010). When these results are compared with our study, it is thought that the reason for the difference is the collection of samples from different localities and the variability of the strains.

In their study, researchers collected M. esculenta and $T$. versicolor mushroom samples from Bolu, Abant region. The antimicrobial activity of the ethanol extracts of the samples against Gram-positive, Gram-negative bacteria and fungi was investigated. No inhibition was detected in 40 and $15 \mu \mathrm{L}$ against $E$. coli strain (Canlı et al., 2019). In our study, M. esculenta ethanol extracts $(60 \mu \mathrm{L})$ showed an inhibition zone of $25 \pm 0.6 \mathrm{~mm}$ against $E$. coli bacteria. In our study, the inhibition zones obtained against the bacteria $P$. aeruginosa DSMZ 50071, S. aureus ATCC 25923 and B. subtilis DSMZ 1971 were much higher than the inhibition obtained in this study.

Table 1. Inhibition zones of antibiotics Gentamycin and Vancomycin were used as a positive control.

\begin{tabular}{l|cc}
\hline \multicolumn{1}{c|}{ Tested Organism } & \multicolumn{2}{|c}{ Inhibition zone (mm) } \\
\cline { 2 - 3 } & Gentamycin (CN) & Vancomycin (VA) \\
\hline Escherichia coli ATCC 25922 & 20 & - \\
Pseudomonas aeruginosa DSMZ 50071 & 20 & 17 \\
Staphylococcus aureus ATCC 25923 & 22 & 8 \\
Bacillus subtilis DSMZ 1971 & 21 & 8 \\
Salmonella typhimurium SL1344 & 21 & \\
\hline
\end{tabular}

Table 2. Antimicrobial activities of crude extracts of T. claveryi collected from Niğde

\begin{tabular}{|c|c|c|c|c|c|c|}
\hline \multirow{3}{*}{ Tested organisms } & \multicolumn{6}{|c|}{ Inhibition zone (mm) } \\
\hline & \multicolumn{3}{|c|}{ Ethanol extract } & \multicolumn{3}{|c|}{ Methanol extract } \\
\hline & 15 & 30 & 60 & 15 & 30 & 60 \\
\hline Escherichia coli ATCC 25922 & $12 \pm 0.6$ & $20 \pm 1.0$ & $27 \pm 0.6$ & $9.7 \pm 0.6$ & $13 \pm 0.6$ & $16 \pm 0.6$ \\
\hline Pseudomonas aeruginosa DSMZ 50071 & $12 \pm 3.2$ & $16 \pm 1.5$ & $23 \pm 3.1$ & $10 \pm 0.0$ & $13 \pm 0.6$ & $17 \pm 0.0$ \\
\hline Staphylococcus aureus ATCC 25923 & $12 \pm 0.6$ & $17 \pm 0.6$ & $19 \pm 0.0$ & $10 \pm 1.2$ & $13 \pm 0.6$ & $16 \pm 0.6$ \\
\hline Bacillus subtilis DSMZ 1971 & $12 \pm 0.6$ & $16 \pm 0.6$ & $21 \pm 1.7$ & $9.3 \pm 0.6$ & $13 \pm 0.6$ & $15 \pm 0.6$ \\
\hline Salmonella typhimurium SL1344 & $12 \pm 0.0$ & $16 \pm 0.6$ & $22 \pm 1.0$ & $8.7 \pm 0.6$ & $14 \pm 0.6$ & $17 \pm 0.6$ \\
\hline \multicolumn{7}{|c|}{ Table 3. Antimicrobial activities of extracts of M. esculenta collected from Niğde } \\
\hline \multirow{3}{*}{ Tested organisms } & \multicolumn{6}{|c|}{ Inhibition zone (mm) } \\
\hline & \multicolumn{3}{|c|}{ Ethanol extract } & \multicolumn{3}{|c|}{ Methanol extract } \\
\hline & 15 & 30 & 60 & 15 & 30 & 60 \\
\hline Escherichia coli ATCC 25922 & $9.7 \pm 0.6$ & $18 \pm 1.0$ & $25 \pm 0.6$ & $10 \pm 0.6$ & $14 \pm 0.0$ & $17 \pm 0.6$ \\
\hline Pseudomonas aeruginosa DSMZ 50071 & $14 \pm 1.2$ & $19 \pm 1.5$ & $25 \pm 0.6$ & $11 \pm 0.6$ & $13 \pm 0.6$ & $17 \pm 0.6$ \\
\hline Staphylococcus aureus ATCC 25923 & $14 \pm 0.6$ & $19 \pm 0.6$ & $23 \pm 0.6$ & $11 \pm 0.6$ & $13 \pm 0.6$ & $16 \pm 1.2$ \\
\hline Bacillus subtilis DSMZ 1971 & $00 \pm 0.0$ & $00 \pm 0.0$ & $00 \pm 0.0$ & $11 \pm 1.2$ & $13 \pm 0.6$ & $15 \pm 1.0$ \\
\hline Salmonella typhimurium SL1344 & $9.3 \pm 0.6$ & $12 \pm 0.6$ & $15 \pm 1.2$ & $11 \pm 0.6$ & $15 \pm 1.2$ & $19 \pm 1.5$ \\
\hline
\end{tabular}




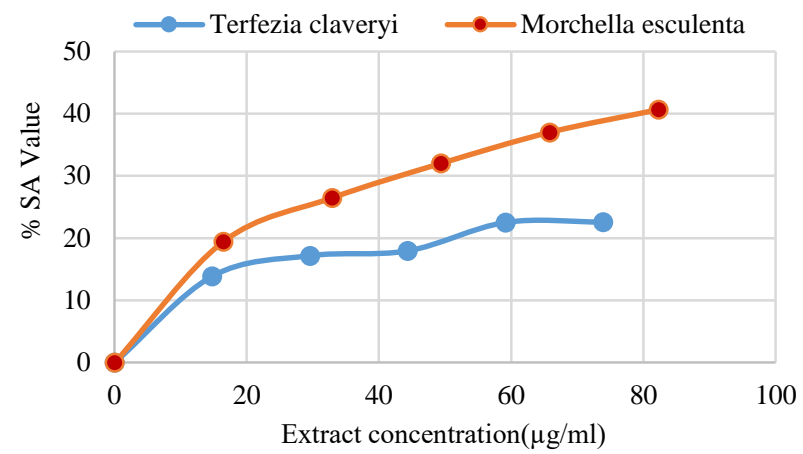

Figure 1. DPPH Scavenging Activities of Fungal Extracts

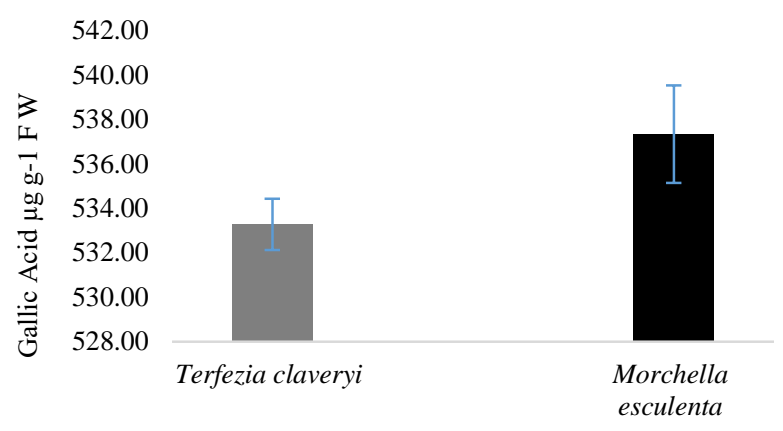

Figure 2. The total phenolic content of Fungi extracts
In the study, it was determined that $M$. esculenta samples did not form an inhibition zone against $E$. coli and B. subtilis strains in hexane, methyl alcohol and ethyl alcohol solvents. It was determined that it formed an inhibition zone against $P$. aeruginosa and $S$. aureus strain (Acay, 2018). The results obtained with $15 \mathrm{mg} / \mathrm{mL}$ methanol extract against these two bacterial strains were similar to the results of this study.

In our study, it was determined that mushroom extracts prepared with different solvents showed different antimicrobial effects against various microorganisms. The results are partially consistent with the findings of previous studies. As a result, it was determined that $T$. claveryi and $M$. esculenta can be a natural antimicrobial agents against the tested bacteria.

\section{Determination of Antioxidant Activities}

It has been stated in many studies that edible mushrooms have powerful antioxidants (Kozarski et al., 2015; Boonsong et al., 2016; Krupodorova and Sevindik, 2020; Roman et al., 2020). In most of the studies, it was stated that there is a positive correlation between the total phenolic content in mushroom extracts and their antioxidative properties, which confirms that edible mushrooms have the potential as natural antioxidants due to the ability of phenolics to inhibit lipid oxidation (Rathee et al., 2012).

The 2,2-diphenyl-1-picrylhydrazyl (DPPH) method is one of the most widely used spectrophotometric methods for the measurement of antioxidant activity (Akar et al., 2017; Szabo et al., 2007). In this study, the antioxidant potential of mushroom extracts was evaluated by the DPPH scavenging method. Free radical scavengers are one of the known mechanisms of antioxidants that inhibit lipid oxidation (Bajpai et al., 2017). The effect of scavenging potential of methanol extracts from fungi on DPPH radicals increased with increasing concentration (Figure 1)

According to Figure 1, among the fungi samples, $M$. esculenta $(82.25 \mu \mathrm{g} / \mathrm{mL})$ had the highest free radical scavenging effect with $40.86 \%$, while $T$. claveryi $(14.78$ $\mu \mathrm{g} / \mathrm{mL}$ ) mushroom showed the lowest free radical scavenging effect with $13.89 \%$.

Kivrak (2015) found that methanol extracts of $T$. claveryi exhibited DPPH with an IC50 of $159.97 \mu \mathrm{g} / \mathrm{mL}$. Saddiq and Danial (2012) found that $T$. claveryi extract has a DPPH activity of $72.6 \%$. Akyuz (2013) found that $T$. boudieri has a DPPH activity of $22.24 \%$. DPPH activity was affected greatly by the extraction solvents (Danham et al., 2018).

When the DPPH scavenging activities we obtained in our study were evaluated, lower results were obtained than in previous studies. It is thought that this difference between the results is due to the difference in the methods applied for extraction, the number of extracts used and the solvents.

Phenolic compounds draw attention with their potential to be beneficial to human health with their functions such as antioxidant, antitumor and antimutagen (Govindarajan et al., 2005). It has been shown in many studies that the antioxidant activity of mushrooms is proportional to the phenolic compounds in their content (Kim et al., 2008; Azieana et al., 2017; Vamanu and Nita, 2013; Vamanu 2014).

As a result of the studies conducted with $T$. claveryi, it has been reported that it has high antioxidant properties, total phenolic content and antimicrobial activity (Saddiq and Danial, 2012). In our study, the total phenolic content of the $T$. claveryi methanol extract was calculated as 533.28 $\pm 1.15 \mu \mathrm{g} \mathrm{GAE} / \mathrm{mg}$ (Figure 2). Wahabi et al. (2016), determined the polyphenol content of $T$. claveryi as (15.4 $\pm 0.11 \mathrm{mg} \mathrm{GAE} / \mathrm{g})$.

The cap structure of M. esculenta has a wide variety of active ingredients, including tocopherols, carotenoids, organic acids, and phenolic compounds (Sevim and Sevim, 2021).

In one study, they determined the total amount of phenolic compounds in $M$. esculenta methanol extract as $47.01 \pm 0.89$ (Wagay et al., 2019). In another study, the total phenolic content of the M. esculenta var. species was determined as $21.33 \pm 1.40 \mu \mathrm{g}$ GAEs/ mg extract. (Gürsoy et al., 2009).

In our study, the phenolic compound content of the methanol extract of M. esculenta was determined as 537.34 $\pm 2.20 \mu \mathrm{g} \mathrm{GAE} / \mathrm{mg}$ (Figure 2).

In this study, the extracts of $T$. claveryi and $M$. esculenta were found to have potent antibacterial and antioxidant properties. Our country is potentially rich in terms of edible macrofungi species. The amount of substance contained in macrofungi varies according to the geographical conditions of the region, genetic factors and collection time. Extracts from macrofungi prepared with various solvents or compounds isolated from them are used in biological activity studies. It is thought that biological activity studies using various extraction methods with mushrooms collected from different regions will play an important role in adding new information to the literature. 
For fungi to be used as medicine or food support, they must be produced in large quantities and of standard quality.

\section{Acknowledgment}

This work was funded by Nigde Omer Halisdemir University Research Projects Unit under the grant no. FEB 2018/18 and authors are thankful for their support.

\section{References}

Acay H. 2018. Assessment Of The Nutritional Qualities And Bioactive Properties of The Wild Edible Mushroom Morchella esculenta (L.) Pers. Mantar Dergisi, 9: 95-105.

Akpi UK, Odoh CK, Ideh EE, Adobu US. 2017. Antimicrobial activity of Lycoperdon perlatum whole fruit body on common pathogenic bacteria and fungi. African Journal of Clinical and Experimental Microbiology, 18(2): 79-85.

Akyüz M. 2013. Nutritive value, flavonoid content and radical scavenging activity of the truffle (Terfezia boudieri Chatin). Journal of soil science and plant nutrition, 13(1): 143-151.

Akyüz M, Kireçci ADÖ, Gökçe Z, Kırbağ S, Yılmz Ö. 2019. Biochemical constituents and antioxidant activities of some mushrooms from Turkey: Agaricus spp., Pleurotus spp., Morchella esculenta and Terfezia boudieri. İstanbul Journal of Pharmacy, 49(1): 1-6.

Badalyan S. 2012. Medicinal aspects of edible ectomycorrhizal mushrooms. In Edible Ectomycorrhizal Mushrooms (pp. 317334). Springer, Berlin, Heidelberg.

Badalyan SM, Barkhudaryan A, Rapior S. 2019. Recent progress in research on the pharmacological potential of mushrooms and prospects for their clinical application. Medicinal Mushrooms, 1-70.

Badotti F, de Oliveira FS, Garcia CF, Vaz ABM, Fonseca PLC, Nahum LA, Oliveira G, Góes-Neto A. 2017. Effectiveness of ITS and sub-regions as DNA barcode markers for the identification of Basidiomycota (Fungi). BMC Microbiology, 17(1): 1-12.

Bajpai VK, Baek KH, Kang SC. 2017. Antioxidant and free radical scavenging activities of taxoquinone, a diterpenoid isolated from Metasequoia glyptostroboides. South African Journal of Botany, 111, 93-98.

Bal C, Sevindik M, Akgul H, Selamoglu Z. 2019. Oxidative stress index and antioxidant capacity of Lepista nuda collected from Gaziantep/Turkey. Sigma, 37(1): 1-5.

Boonsong S, Klaypradit W, Wilaipun P. 2016. Antioxidant activities of extracts from five edible mushrooms using different extractants. Agriculture and Natural Resources, 50(2): 89-97.

Breitenbach, J. and Kränzlin, F. 1984. Fungi of Switzerland, Vol: 1, Ascomycetes, Verlag Mykologia CH-6000 Luzern 9, 310 p., Switzerland.

Canlı K, Benek A, Şenturan M, Akata I, Altuner EM. 2019. In vitro Antimicrobial Activity of Morchella esculenta and Trametes versicolor. Mantar Dergisi, 10(3): 28-33.

Dahham SS, Al-Rawi SS, Ibrahim AH, Majid ASA, Majid AMSA. 2018. Antioxidant, anticancer, apoptosis properties and chemical composition of black truffle Terfezia claveryi. Saudi Journal of Biological Sciences, 25(8): 1524-1534.

Doğan HH, Aydin S. 2013. Determination of antimicrobial effect, antioxidant activity and phenolic contents of desert truffle in Turkey. African Journal of Traditional, Complementary and Alternative Medicines, 10(4): 52-58.

Doğan HH, Duman R, Özkalp B, Aydin S. 2013. Antimicrobial activities of some mushrooms in Turkey. Pharmaceutical Biology, 51(6): 707-711.

Duman R, Doğan HH, Ateş A. 2003. Morchella conica (Pers.) Boudier ve Suillus luteus (L.) SF Gray Makrofunguslarının Antimikrobiyal Aktiviteleri. Selçuk Üniversitesi Fen Fakültesi Fen Dergisi, 1(22): 19-24.
Eraslan EC, Altuntas D, Baba H, Bal C, Akgül H, Akata I, Sevındık M. 2021. Some Biological Activities and Element Contents of Ethanol Extract of Wild Edible Mushroom Morchella esculenta. Sigma: Journal of Engineering and Natural Sciences, 39(1): 24-28.

Giusti A, Ricci E, Gasperetti L, Galgani M, Polidori L, Verdigi F, Narducci R, Armani A. 2021. Molecular identification of mushroom species in Italy: An ongoing project aimed at reinforcing the control measures of an increasingly appreciated sustainable food. Sustainability, 13(1): 238(1-8).

Gücin F. Dülger B. 1997. Yenen ve Antimikrobiyal Aktiviteleri Olan Keme Mantarı (= terfezia boudieri chatin) Üzerinde Araştırmalar. Ekoloji, 6(23): 27-33.

Hussain G, Al-Ruqaie I.M. 1999. Occurrence, chemical composition, and nutritional value of truffles: an overview, Pakistan Journal of Biological Sciences, 2: 510- 514.

İnci Ş, Kırbağ S. 2018. Terfezia claveryi Chatin'in besinsel içeriği, antioksidan ve antimikrobiyal aktivitesi. Artvin Çoruh Üniversitesi Orman Fakültesi Dergisi, 19(2): 138-143.

Islek C, Saridogan BGO, Sevindik M, Akata I. 2021. Biological Activities and Heavy Metal Contents of Some Pholiota Species. Fresenius Environmental Bulletin, 30(06): 61096114.

Janakat S, AlFakhiri S, Sallal A.K. 2004. A promising peptide antibiotic from Terfezia claveryi aqueous extract against Staphylococcus aureus in vitro. Phytotherapy Research: An International Journal Devoted to Pharmacological and Toxicological Evaluation of Natural Product Derivatives, 18(10): 810-813.

Kıvrak İ. 2015. Analytical methods applied to assess chemical composition, nutritional value and in vitro bioactivities of Terfezia olbiensis and Terfezia claveryi from Turkey. Food Analytical Methods, 8(5): 1279-1293.

Kim MY, Seguin P, Ahn JK, Kim JJ, Chun SC, Kim EH, Seo SY, Kang EY, Kim SL, Park YJ, Ro HM, Chung, I. M. 2008. Phenolic compound concentration and antioxidant activities of edible and medicinal mushrooms from Korea. Journal of Agricultural and Food Chemistry, 56(16). 7265-7270.

Krupodorova T, Sevindik M. 2020. Antioxidant potential and some mineral contents of wild edible mushroom Ramaria stricta. AgroLife Scientific Journal, 9(1): 186-191.

Lindequist U, Niedermeyer TH, Jülich WD. 2005. The pharmacological potential of mushrooms. Evidence-based complementary and alternative medicine, 2(3): 285-299.

Rathee S, Rathee D, Rathee D, Kumar V, Rathee P. 2012. Mushrooms as therapeutic agents. Revista Brasileira de Farmacognosia, 22: 459-474.

Román MPG, Mantilla NB, Flórez SAC, De Mandal S, Passari AK, Ruiz-Villáfan B, Rodríguez-Sanoja R, Sánchez S. 2020. Antimicrobial and Antioxidant Potential of Wild Edible Mushrooms. In An Introduction to Mushroom (pp. 1-18). IntechOpen.

Saddiq AA, Danial EN. 2012. Assessment of phenolic content, free radical-scavenging capacity and antimicrobial activities of Truffle clavery. Wulfenia Journal, 19: 403-422.

Saridogan BGO, Islek C, Baba H, Akata I, Sevindik M. 2021. Antioxidant Antimicrobial Oxidant and Elements Contents Of Xylarıa Polymorpha And X. Hypoxylon (Xylariaceae). Fresenius Environmental Bulletin, 30(5): 5400-5404.

Schoch CL, Seifert KA, Huhndorf S, Robert V, Spouge JL, Levesque CA, Chen W, Fungal Barcoding Consortium. 2012. Nuclear ribosomal internal transcribed spacer (ITS) region as a universal DNA barcode marker for Fungi. Proceedings of the National Academy of Sciences, 109(16): 6241-6246.

Sevim E, Sevim A. 2021. Kırşehir İlinden Toplanan Morchella esculenta (L.) Pers (Kuzu Göbeği) Mantarlarının Moleküler Karakterizasyonu ve Antimikrobiyal Aktivitelerinin Belirlenmesi. Journal of Advanced Research in Natural and Applied Sciences, 7(1): 48-59. 
Sevindik M, Akgül H, Günal S, Doğan M. 2016. Pleurotus ostreatus'un doğal ve kültür formlarının antimikrobiyal aktiviteleri ve mineral madde içeriklerinin belirlenmesi. Kastamonu University Journal of Forestry Faculty, 16(1): 153-156

Sevindik M. 2020. Antioxidant and antimicrobial capacity of Lactifluus rugatus and its antiproliferative activity on A549 cells. Indian Journal of Traditional Knowledge (IJTK), 19(2): 423-427.

Sevindik M, Akgul H, Korkmaz AI, Sen I. 2018. Antioxidant potantials of Helvella leucomelaena and Sarcosphaera coronaria. J Bacteriol Mycol Open Access, 6(2): 00173.

Sevindik M, Akata I. 2019. Antioxidant, oxidant potentials and element content of edible wild mushroom Helvella leucopus. Indian Journal of Natural Products and Resources, 10(4): 266-271.

Shimada K, Fujikawa K, Yahara K, Nakamura T. 1992. Antioxidative properties of xanthan on the autoxidation of soybean oil in cyclodextrin emulsion. Journal of agricultural and food chemistry, 40(6): 945-948.

Singleton VL, Orthofer R, Lamuela-Raventós RM. 1999. Analysis of total phenols and other oxidation substrates and antioxidants by means of folin-ciocalteu reagent. Methods in enzymology, 299: 152-178.

Taşkın H, Süfer Ö, Attar ŞH, Bozok F, Baktemur G, Büyükalaca S, Kafkas NE. 2021. Total phenolics, antioxidant activities and fatty acid profiles of six Morchella species. Journal of Food Science and Technology, 58(2): 692-700.
Vamanu E. 2014. Antioxidant properties of mushroom mycelia obtained by batch cultivation and tocopherol content affected by extraction procedures. BioMed Research International, doi.org/10.1155/2014/974804.

Vamanu E. Nita S. 2013. Antioxidant capacity and the correlation with major phenolic compounds, anthocyanin, and tocopherol content in various extracts from the wild edible Boletus edulis mushroom. BioMed Research International, doi.org/10.1155/2013/313905.

Vu D, Groenewald M, De Vries M, Gehrmann T, Stielow B, Eberhardt U, Al-Hatmi A, Groenewald JZ, Cardinali G, Houbraken J, Boekhout T, Crous PW, Robert V, Verkley GJM. 2019. Large-scale generation and analysis of filamentous fungal DNA barcodes boosts coverage for kingdom fungi and reveals thresholds for fungal species and higher taxon delimitation. Studies in mycology, 92: 135-154.

Wagay JA, Nayik GA, Wani SA, Mir RA, Ahmad MA, Rahman QI, Vyas D. 2019. Phenolic profiling and antioxidant capacity of Morchella esculenta L. by chemical and electrochemical methods at multiwall carbon nanotube paste electrode. Journal of Food Measurement and Characterization, 13(3): 1805-1819.

Wahiba B, Wafaà T, Asmaà K, Bouziane A, Mohammed B. 2016. Nutritional and antioxidant profile of red truffles (Terfezia claveryi) and white truffle (Tirmania nivea) from southwestern of Algeria. Der Pharmacia Letter, 8: 134-141.

White TJ, Bruns T, Lee SJWT, Taylor J. 1990. Amplification and direct sequencing of fungal ribosomal RNA genes for phylogenetics. PCR protocols: a guide to methods and applications, 18(1): 315-322. 